\title{
Pengembangan Perangkat Pembelajaran Matematika BERBASIS GUIDED INQUIRY DAN LEARNING TRAJECTORY BERORIENTASI PADA KEMAMPUAN PEMECAHAN MASAlaH
}

\author{
Viani Kurniawati ${ }^{*}$ dan Ilham Rizkianto ${ }^{2}$ \\ 1Jurusan Pendidikan Matematika, Universitas Negeri Yogyakarta \\ Jalan Colombo No. 1, Karangmalang, Yogyakarta 55281, Indonesia \\ viani.kurniawati@student.uny.ac.id \\ 2 Jurusan Pendidikan Matematika, Universitas Negeri Yogyakarta \\ Jalan Colombo No. 1, Karangmalang, Yogyakarta 55281, Indonesia \\ ilham_rizkianto@uny.ac.id
}

Artikel diterima: 26 Mei 2018, direvisi: 9 September 2018, diterbitkan: 30 September 2018

\begin{abstract}
Abstrak
Penelitian ini bertujuan untuk mengembangkan perangkat pembelajaran matematika berupa RPP dan LKS menggunakan pendekatan guided inquiry yang mengacu pada learning trajectory dan berorientasi pada kemampuan pemecahan masalah siswa. Jenis penelitian ini adalah penelitian pengembangan dengan model pengembangan ADDIE yang terdiri dari tahap Analysis, Design, Development, Implementation, dan Evaluation. Sampel data sebanyak satu kelas secara acak yaitu siswa kelas VII A SMP Negeri 2 Pleret sejumlah 32 siswa. Berdasarkan penilaian kevalidan, RPP memenuhi kriteria valid dengan skor 4,13, sedangkan LKS memenuhi kriteria sangat valid dengan skor 4,22. Berdasarkan penilaian kepraktisan, perangkat pembelajaran memenuhi kriteria praktis dengan skor angket respon siswa 3,38 dan persentase keterlaksanaan pembelajaran mencapai $97 \%$. Berdasarkan penilaian keefektifan dari tes kemampuan pemecahan masalah, diperoleh nilai rata-rata ketercapaian kemampuan pemecahan masalah 78 dan siswa yang mencapai kemampuan pemecahan masalah minimal pada kategori baik sebesar $84,38 \%$. One sample t-test menunjukkan bahwa nilai rata-rata ketercapaian kemampuan pemecahan masalah siswa lebih dari 60, sedangkan uji z menunjukkan bahwa persentase siswa yang mencapai kemampuan pemecahan masalah minimal pada kategori baik lebih dari $70 \%$.

Kata Kunci: perangkat pembelajaran, guided inquiry, learning trajectory, pemecahan masalah

Abstract (Developing Mathematics Learning Material based on Guided Inquiry And Learning Trajectory With An Orientation on Problem Solving Skill)

The present research project aims to develop mathematics learning material that includes lesson plan and student worksheets based on guided inquiry approach and learning trajectory with an orientation on problem solving skill. Type of the research project was reseach and development with ADDIE model, consisting of Analysis, Design, Development, Implementation, and Evaluation. The sample of one person was directly conducted, consisting of 32 students of class VII A of Pleret State 2 Junior High School. Based on the result of validation assessment, the lesson plan is "valid" with a score of 4.13, while validation assessment of student worksheets is "very valid", obtaining a score 4.22. Based on the result of practicality, the learning material is "practical" with a score 3.38 and learning implementation percentage is $97 \%$. Based on the effectiveness assessment using problem solving skill test, the average score of the class was 78 and $84.38 \%$ of students have a minimum problem solving skill in the "good" category. One sample t-test show that the average score of the class was higher than 60, while z-test with show that more than $70 \%$ of students have a minimum problem solving skill in the "good" category.

Keyword: learning material, guided inquiry, learning trajectory, problem solving skill.
\end{abstract}




\section{Pendahuluan}

Hasil dari The Programme for International Student Assessment (PISA) menunjukkan bahwa performance of mathematics siswa di Indonesia masih berada di bawah rata-rata OECD (OECD, 2016). Sejak tahun 2009 hingga PISA yang terakhir yaitu tahun 2015, perolehan skor Indonesia memang meningkat. Namun rata-rata tersebut belum pernah mencapai rata-rata OECD. Pada tahun 2009, nilai rata-rata perolehan skor Indonesia sebesar 371 dan rata-rata skor OECD adalah 496. Pada tahun 2012, perolehan skor rata-rata Indonesia sebesar 375 dan rata-rata skor OECD adalah 494. Pada tahun 2015, Indonesia memperoleh skor rata-rata sebesar 386, padahal rata-rata skor OECD untuk literasi matematika adalah 490. Di samping itu, skor minimum untuk berada pada level 6 (level kemampuan tertinggi) pada tes PISA yaitu 669 (Shiel et al., 2007: 20). Skor yang diperoleh Indonesia tentu masih jauh dari batas minimum tersebut, sehingga dapat dikatakan bahwa performance of mathematics di Indonesia masih rendah.

Salah satu kemungkinan dari penyebab rendahnya performance of mathematics di Indonesia yaitu rendahnya kemampuan pemecahan masalah matematis siswa Indonesia. Gagne (dalam Suherman et al., 2001: 89) berpendapat bahwa keterampilan intelektual tinggi dapat dikembangkan melalui kemampuan pemecahan masalah. Artinya, rendahnya performance of mathematics di Indonesia ini dapat ditingkatkan melalui kemampuan pemecahan masalah yang baik. Peraturan menteri pendidikan dan kebudayaan (Permendikbud) Nomor 58 Tahun 2014 menyebutkan bahwa salah satu tujuan mata pelajaran matematika untuk Sekolah Menengah Pertama yaitu memecahkan masalah (Kemendikbud, 2014). Hal tersebut juga sejalan dengan salah satu dari kecakapan abad 21 yang dikembangkan oleh Partnership for $21^{\text {st }}$ century skills (P21), yaitu berpikir kritis dan pemecahan masalah (P21, 2015: 3-9). Pentingnya pemecahan masalah matematika ini ditegaskan pula oleh National Council of Teacher of Mathematics (NCTM), yang menyatakan bahwa pemecahan masalah merupakan bagian integral dalam pembelajaran matematika, sehingga hal tersebut tidak boleh dilepaskan dari pembelajaran matematika (NCTM, 2000: 52).

Lestari \& Yudhanegara (2015: 84) mengemukakan bahwa kemampuan pemecahan masalah adalah kemampuan menyelesaikan masalah rutin, non-rutin, baik terapan maupun non terapan, dalam bidang matematika. Terdapat dua penelitian relevan telah mengkaji keresahan para peneliti terhadap kemampuan pemecahan masalah matematis siswa, yaitu: Keterkaitannya dengan kemampuan problem posing (Afriansyah, 2016), dan keterkaitannya dengan self-confidence siswa (Dewi \& Minarti, 2018) Untuk mengembangkan kemampuan pemecahan masalah yang baik, dapat dilakukan dengan 
mengembangkan RPP dan LKS yang sesuai dengan kurikulum 2013.

RPP adalah suatu rencana yang menggambarkan manajemen kegiatan untuk mencapai satu kompetensi dasar (Trianto, 2010: 108). Sedangkan LKS adalah panduan bagi siswa dalam melakukan kegiatan penyelidikan atau pemecahan masalah (Trianto, 2010: 111). Perangkat pembelajaran harus memenuhi kualitas yang baik agar dapat mewujudkan pembelajaran yang efektif dan dapat memotivasi siswa dalam belajar.

Menurut Nieveen (1999: 126), kualitas suatu produk pengembangan pendidikan harus memenuhi 3 kriteria yaitu kevalidan, kepraktisan, dan keefektifan. Menurut standar proses yang tercantum pada Permendikbud Nomor 65 Tahun 2013, perangkat pembelajaran kurikulum 2013 ditekankan pada pendekatan scientific (ilmiah) dengan pembelajaran berbasis penemuan mapun penyelidikan (discovery/inquiry learning) (Kemendikbud, 2013). Sedangkan, tujuan dari guided inquiry adalah untuk mendampingi siswa dalam proses pemecahan masalah dan penerapan pemahaman siswa terhadap situasi baru (Kuhlthau, Maniotes, \& Caspari, 2007: 97).

Menurut Sanjaya (2006: 196), pembelajaran inquiry adalah rangkaian kegiatan yang menekankan pada proses berpikir kritis analitis untuk mencari dan menemukan sendiri jawaban dari masalah yang dipertanyakan. Uno (2016: 14) menyampaikan bahwa inquiry bertujuan melatih kemampuan siswa dalam meneliti, menjelaskan, dan memecahkan masalah secara ilmiah. Menurut Kuhlthau, Maniotes, \& Caspari, (2012: 2-5), tahaptahap guided inquiry meliputi: open, immerse, explore, identify, gather, create, share, evaluate.

Dalam Permendikbud Nomor 22 Tahun 2016, disebutkan bahwa prinsip penyusunan dan pengembangan RPP adalah memperhatikan perbedaan individual siswa antara lain kemampuan awal, tingkat intelektual, bakat, potensi, minat, motivasi belajar, kemampuan sosial, emosi, gaya belajar, kebutuhan khusus, kecepatan belajar, latar belakang budaya, norma, nilai, dan/atau lingkungan siswa (Kemendikbud, 2016). Dapat disimpulkan bahwa RPP yang dikembangkan sebaiknya memperhatikan alur berpikir siswa (learning trajectory).

Menurut Simon (1995: 135), hypothetical learning trajectory memungkinkan guru untuk membuat desain pembelajaran tertentu, sehingga guru dapat memperkirakan bagaimana proses belajar yang sedang berlangsung. Hal tersebut dapat ditunjukkan dengan membuat perencanaan pembelajaran di setiap situasi untuk menanggapi pemikiran siswa. Clements \& Sarama (dalam Daro et al., 2011: 23) berpendapat bahwa learning trajectory matematika merupakan deskripsi pemikiran dan belajar anak-anak dalam domain matematika tertentu dan menduga lintasan belajar melalui serangkaian tugas intruksional yang telah dirancang. Menurut Daro et al. (2011: 23), tiga komponen utama pada learning 
trajectory meliputi: tugas-tugas yang diduga dapat menimbulkan proses mental siswa, dugaan respon siswa sesuai tingkat perkembangan berpikir siswa, dan tujuan pembelajaran yang diinginkan. Peneliti melakukan kajian secara teoritis, observasi, dan eksperimen dengan bimbingan dari supervisor dalam mendesain suatu dugaan rangkaian aktivitas pembelajaran matematika, yaitu Hypothetical Learning Trajectory (HLT). (Afriansyah, 2017)

Dari uraian tersebut, pengembangan perangkat pembelajaran berupa RPP dan LKS yang berbasis pendekatan guided inquiry yang mengacu pada learning trajectory dapat memfasilitasi siswa untuk mengembangkan kemampuan pemecahan masalah. Langkah pembelajaran yang digunakan pada penelitian ini meliputi: open, immerse, explore, identify, gather, create, share, dan evaluate (diadaptasi dari Kuhlthau, Maniotes, \& Caspari, 2012: 2-5). Indikator kemampuan pemecahan masalah yang digunakan adalah: (1) memahami masalah; (2) merencanakan penyelesaian atau memodelkan masalah; (3) menyelesaikan masalah; (4) menuliskan kesimpulan berdasarkan masalah yang diberikan (diadaptasi dari Lestari \& Yudhanegara, 2015: 85).

\section{MetOde}

Jenis penelitian yang dilakukan adalah Research and Development (R\&D). Model pengembangan yang digunakan adalah model pengembangan ADDIE. Tahaptahap pengembangan ini meliputi Analysis,
Design, Development, Implementation, dan Evaluation (Pribadi, 2009: 127).

Pada tahap pertama, yaitu analysis, kompetensi, karakteristik siswa, dan pembelajaran dianalisis. Hal tersebut dilakukan untuk memperoleh indikator pencapaian kompetensi dan pendekatan yang diperlukan oleh siswa dalam pembelajaran. Setelah melakukan tahap analisis, tahap selanjutnya yang dilakukan peneliti adalah mendesain perangkat pembelajaran bedasarkan hasil analisis yang meliputi penyusunan rancangan RPP, penyusunan rancangan LKS, dan penyusunan rancangan instrumen penilaian produk yang dikembangkan. Selanjutnya pada tahap pengembangan, rancangan yang dihasilkan pada tahap desain direalisasikan menjadi produk, divalidasi oleh dosen ahli dan guru matematika, direvisi, sedemikian sehingga siap diimplementasikan pada pembelajaran. Tahap keempat adalah tahap implementation. Pada tahap ini, peneliti menggunakan satu kelas uji coba yang menggunakan RPP dan LKS yang dikembangkan. Tahap yang terakhir dari model pengembangan ADDIE yaitu evaluate. Pada tahap ini, dilakukan analisis kepraktisan dan keefektifan LKS yang telah diujicobakan kepada siswa.

Penelitian dilakukan pada tanggal 1-17 Februari 2018. Populasi penelitian ini adalah siswa kelas VII SMP N 2 Pleret. Kemudian dipilih sampel data sebanyak satu kelas secara acak yaitu siswa kelas VII A SMP Negeri 2 Pleret sejumlah 32 siswa. 
Instrumen yang digunakan dalam penelitian ini adalah (1) instrumen untuk mengukur kevalidan berupa lembar penilaian LKS dan lembar penilaian RPP; (2) instrumen untuk mengukur kepraktisan berupa angket respon siswa lembar observasi keterlaksanaan pembelajaran; (3) instrumen untuk mengukur keefektifan yaitu data hasil tes kemampuan pemecahan masalah.

Data kuantitatif berskala 5 dikonversikan menjadi data kualitatif menggunakan acuan Tabel 1 berikut (Widyoko, 2009: 238).

Tabel 1.

Konversi Skor Penilaian Skala 5

\begin{tabular}{|cc|}
\hline Rentang Skor & Kategori \\
\hline $\bar{x}>\mathbf{4 , 2 0}$ & Sangat Valid \\
\hline $\mathbf{3 , 4 0}<\overline{\boldsymbol{x}} \leq \mathbf{4 , 2 0}$ & Valid \\
\hline $2, \mathbf{6 0}<\overline{\boldsymbol{x}} \leq \mathbf{3 , 4 0}$ & Cukup Valid \\
\hline $\mathbf{1 , 8 0}<\overline{\boldsymbol{x}} \leq \mathbf{2 , 6 0}$ & Kurang Valid \\
\hline $\bar{x}>\mathbf{1 , 8 0}$ & Sangat Kurang Valid \\
\hline
\end{tabular}

Keterangan: $\bar{x}=$ rata-rata perolehan skor

Perangkat pembelajaran dapat dikatakan valid jika rata-rata penilaian oleh validator berada minimal pada kategori "valid".

Sedangkan data kuantitatif berskala 4 dikonversikan menjadi data kualitatif menggunakan acuan Tabel 2 berikut (Widyoko, 2009: 238).

Tabel 2.

Konversi Skor Penilaian Skala 4

\begin{tabular}{|cc|}
\hline Rentang Skor & Kategori \\
\hline $\bar{x}>\mathbf{3 , 4 0}$ & Sangat Praktis \\
\hline $\mathbf{2 , 8 0}<\overline{\boldsymbol{x}} \leq \mathbf{3 , 4 0}$ & Praktis \\
\hline $\mathbf{2 , 2 0}<\overline{\boldsymbol{x}} \leq \mathbf{2 , 8 0}$ & Cukup Praktis \\
\hline $\mathbf{1 , 6 0}<\overline{\boldsymbol{x}} \leq \mathbf{2 , 2 0}$ & Kurang Praktis \\
\hline$\overline{\boldsymbol{x}}>\mathbf{1 , 6 0}$ & Sangat Kurang \\
& Praktis \\
\hline
\end{tabular}

Keterangan: $\bar{x}=$ rata-rata perolehan skor

Mosharafa: Jumal Pendidikan Matematika

Volume 7, Nomor 3, September 2018
Selanjutnya, perangkat pembelajaran dikatakan praktis jika hasil data respon siswa dan guru minimal pada kategori "praktis".

Keefektifan perangkat pembelajaran dilihat dengan mengacu pada Tabel 3 berikut (Widyoko, 2017: 242).

Tabel 3.

Konversi Skor Penilaian Keefektifan

Persentase Kategori

Ketuntasan (dalam \%)

\begin{tabular}{|cc|}
\hline \multicolumn{1}{c|}{$>80$} & Sangat Baik \\
\hline $\mathbf{6 0}<\boldsymbol{p} \leq \mathbf{8 0}$ & Baik \\
\hline $\mathbf{4 0}<\boldsymbol{p} \leq \mathbf{6 0}$ & Cukup \\
\hline $\mathbf{2 0}<\boldsymbol{p} \leq \mathbf{4 0}$ & Kurang \\
\hline$\leq 20$ & Kurang Sekali \\
\hline
\end{tabular}

Perangkat pembelajaran dikatakan efektif jika rata-rata perolehan skor tes kemampuan pemecahan masalah minimal pada kategori "baik" dan persentase siswa yang memiliki kemampuan pemecahan masalah minimal "baik" lebih dari 70\%.

\section{Hasil dan Pembahasan}

\section{A. HASIL}

1. Tahap Analisis (Analysis)

Kompetensi yang digunakan dalam pembelajaran matematika mengacu pada kurikulum 2013. Hasil dari analisis materi Aritmetika Sosial yang meliputi sub materi: (1) keuntungan dan kerugian, (2) bunga tunggal, (3) diskon dan pajak, serta (4) bruto, neto, dan tara.

Menurut teori perkembangan kognitif yang dikemukakan Piaget (dalam Siswoyo et al., 2013:100), siswa SMP kelas VII berada pada tahap operasional formal, artinya anak sudah mampu menuliskan masalah matematika menggunakan simbol maupun model matematika yang 
menggambarkan suatu permasalahan. Uno (2016: 14) menyampaikan bahwa inquiry bertujuan melatih kemampuan siswa dalam meneliti, menjelaskan, dan memecahkan masalah secara ilmiah. Berdasarkan hal-hal tersebut, maka untuk siswa SMP kelas VII pendekatan pembelajaran berbasis guided inquiry dapat digunakan, sedemikian sehingga dapat memfasilitasi siswa dalam menyelesaikan suatu masalah matematika.

Hasil dari analisis pembelajaran yaitu dalam proses pembelajaran terjadi interaksi multi arah antara guru dan siswa, siswa dan siswa, serta siswa dan lingkungan. Stimulus yang diberikan oleh guru akan mendapat respon yang beragam dari siswa. Dalam hal ini, guru harus mempersiapkan alternatif respon untuk memfasilitasi keberagaman kemampuan siswa. Dengan kata lain, perangkat pembelajaran perlu mengacu pada learning trajectory.

\section{Tahap Perancangan (Design)}

Berdasarkan rumusan $\mathrm{Kl}, \mathrm{KD}$, dan indikator, disusun 4 RPP untuk 4 pertemuan dengan total 10 jam pelajaran (10×40 menit) dengan rincian pertemuan 1 sebanyak 3 JP, pertemuan 2 sebanyak 2 $J P$, pertemuan 3 sebanyak $3 \mathrm{JP}$, dan pertemuan 4 sebanyak 2 JP. RPP dikembangkan menurut prinsip pengembangan dan komponen RPP disusun berdasarkan Permendikbud Nomor 22 Tahun 2016. Alokasi waktu pada setiap bagian dirancang sesuai model format RPP yang sesuai dengan Permendikbud Nomor 22 Tahun 2016. Kegiatan Pembuka dirancang dengan alokasi waktu 10\%, kegiatan inti sebanyak
$75 \%$, dan kegiatan penutup sebanyak $15 \%$ dari total alokasi waktu pada satu pertemuan.

Menurut model format RPP yang sesuai dengan Permendikbud Nomor 22 Tahun 2016, langkah pembelajaran disajikan menjadi dua kolom yaitu aktivitas siswa dan aktivitas guru dengan waktu disajikan secara kumulatif pada tiap bagian saja. Namun, RPP ini dirancang mengacu pada learning trajectory yang memuat tiga komponen seperti yang diungkapkan Daro et al., (2011: 23), diantaranya kegiatan siswa, dugaan respon siswa, dan tujuan pembelajaran yang jelas. Oleh karena itu, penyajian langkah pembelajaran dirancang dengan sebuah tabel yang terdiri dari lima kolom yang berisi aktivitas guru, aktivitas siswa, dugaan respon siswa, alternatif respon guru, dan alokasi waktu.

Langkah pembelajaran yang digunakan dalam RPP sesuai pendapat Kuhlthau, Maniotes, \& Caspari (2012: 2-5) yaitu open (apersepsi), immerse (pengenalan), explore (eksplorasi), identify (merumuskan masalah), gather (mengumpulkan informasi), create (mencipta), share (mengkomunikasi), evaluate (evaluasi).

LKS terdiri atas KD, indikator, tujuan pembelajaran, dan petunjuk pengerjaan LKS. LKS dirancang dengan kegiatankegiatan dengan sintaks guided inquiry yang berupa kegiatan Mari Mengingat Kembali (Open), Mari Mengenal (Immerse), Mari Mengenal Lebih Jauh (Explore), Mari Merumuskan Pertanyaan (Identify), Mari Mengumpulkan Informasi (Gather), Mari Mencipta (Create), Mari 
Presentasikan (Share), dan Mari Menentukan Solusi (Evaluate). Untuk mencapai tahap-tahap tersebut dilakukan dengan cara: (1) Disajikan masalah nyata; (2) Diberikan pertanyaan terbimbing untuk menentukan keputusan dari masalah; (3) siswa diminta merumuskan pertanyaan dari masalah; (4) siswa diminta mencari jawaban dari pertanyaan melalui kegiatan mengisi tabel dengan bantuan buku; (5) siswa dibimbing menggeneralisasikan jawabannya pada kegiatan 4; (6) siswa diminta mempresentasikan pekerjaannya; (7) siswa diminta menyelesaikan suatu masalah secara mandiri.

\section{Tahap Pengembangan (Development)}

Pada tahap ini perangkat pembelajaran dikembangkan sesuai rancangan yang telah disusun serta validasi produk oleh dosen ahli dan guru. Hasil penilaian RPP dan LKS oleh validator memiliki skor maksimal 5 dan disajikan dalam Tabel 4 dan 5 .

Tabel 5.

Hasil Analisis Penilaian RPP

\begin{tabular}{lcc|}
\hline \multicolumn{1}{|c}{ Aspek Penilaian } & $\begin{array}{c}\text { Skor Rata- } \\
\text { Rata }\end{array}$ & Kategori \\
\hline Identitas RPP & 4,50 & $\begin{array}{c}\text { Sangat } \\
\text { Valid }\end{array}$ \\
\hline $\begin{array}{l}\text { Rumusan Tujuan } \\
\text { Pembelajaran }\end{array}$ & 3,83 & Valid \\
\hline Materi Pokok & 4 & Valid \\
\hline Alokasi Waktu & 4 & Valid \\
\hline $\begin{array}{l}\text { Metode } \\
\text { Pembelajaran }\end{array}$ & 4 & Valid \\
\hline $\begin{array}{l}\text { Media dan Sumber } \\
\text { Belajar }\end{array}$ & 3,80 & Valid \\
\hline $\begin{array}{l}\text { Langkah-Langkah } \\
\text { Kegiatan } \\
\text { Pembelajaran }\end{array}$ & 4,19 & Valid \\
\hline Penilaian & 4 & Valid \\
\hline \multicolumn{1}{|l}{ Kesimpulan } & 4,13 & Valid \\
\hline
\end{tabular}

Tabel 5.

Hasil Analisis Penilaian LKS

\begin{tabular}{lcc|}
\hline \multicolumn{1}{|c}{ Aspek Penilaian } & $\begin{array}{c}\text { Skor Rata- } \\
\text { Rata }\end{array}$ & Kategori \\
\hline $\begin{array}{l}\text { Kesesuaian dengan } \\
\text { syarat didaktis }\end{array}$ & 4,13 & Valid \\
\hline $\begin{array}{l}\text { Kesesuaian dengan } \\
\text { syarat teknis }\end{array}$ & 4,38 & $\begin{array}{c}\text { Sangat } \\
\text { Valid }\end{array}$ \\
\hline $\begin{array}{l}\text { Kesesuaian } \\
\text { Materi/isi }\end{array}$ & 4 & Valid \\
\hline $\begin{array}{l}\text { Kesesuaian LKS } \\
\text { berbasis guided } \\
\text { inquiry yang } \\
\text { mengacu pada } \\
\text { learning trajectory }\end{array}$ & 4,13 & Valid \\
\hline $\begin{array}{l}\text { Kesesuaian dengan } \\
\text { syarat teknis }\end{array}$ & 4,35 & $\begin{array}{c}\text { Sangat } \\
\text { Valid }\end{array}$ \\
\hline \begin{tabular}{l} 
Kesimpulan \\
\hline
\end{tabular} & 4,22 & $\begin{array}{l}\text { Sangat } \\
\text { Valid }\end{array}$ \\
\hline
\end{tabular}

Berdasarkan Tabel 4 dan 5, RPP dan LKS valid untuk diujicobakan.

4. Tahap Implementasi (Implementation)

Hasil dari tahap ini adalah hasil respon siswa, tes kemampuan pemecahan masalah, dan data observasi keterlaksanaan pembelajaran.

\section{Tahap Evaluasi (Evaluation)}

Hasil dari tahap evaluasi adalah hasil analisis kepraktisan dan keefektifan dari perangkat pembelajaran yang dikembangkan. Hasil analisis respon siswa dan analisis keterlaksanaan pembelajaran dapat dilihat pada Tabel 6 dan 7.

Tabel 6.

Hasil Analisis Angket Respon Siswa

\begin{tabular}{lcc|}
\hline \multicolumn{1}{|c}{ Aspek Penilaian } & $\begin{array}{c}\text { Skor Rata- } \\
\text { Rata }\end{array}$ & Kategori \\
\hline $\begin{array}{l}\text { Ketepatan } \\
\text { penggunaan } \\
\text { Bahasa }\end{array}$ & 3,23 & Praktis \\
\hline Materi/isi LKS & 3,34 & Praktis \\
\hline $\begin{array}{l}\text { Penggunaan LKS } \\
\text { dalam } \\
\text { Pembelajaran }\end{array}$ & 3,53 & $\begin{array}{l}\text { Sangat } \\
\text { Praktis }\end{array}$ \\
\hline Kemenarikan & 3,34 & Praktis \\
\hline \multicolumn{1}{c}{ Kesimpulan } & 3,38 & Praktis \\
\hline
\end{tabular}


Tabel 7.

Analisis Keterlaksanaan Pembelajaran

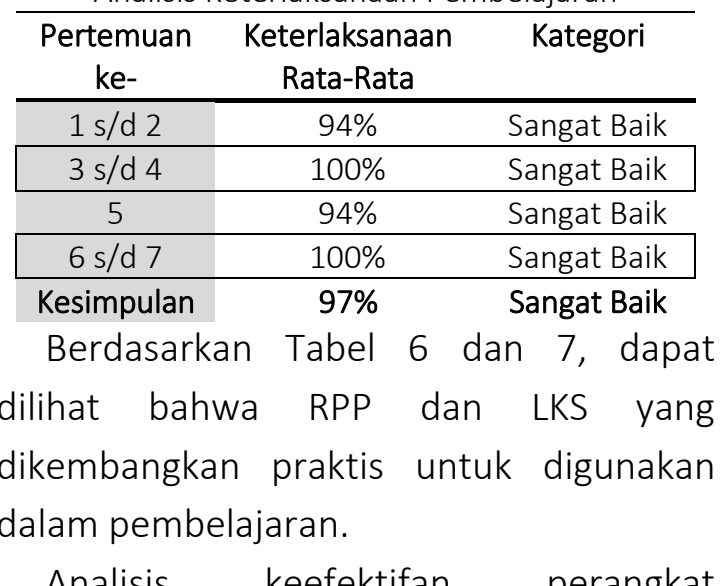
pembelajaran adalah sebagai berikut.

a. Hasil rata-rata tes kemampuan pemecahan masalah minimal baik.

Hasil analisis butir kemampuan pemecahan masalah dapat dilihat pada Tabel 8.

Tabel 8.

Hasil Analisis Butir Kemampuan Pemecahan Masalah

\begin{tabular}{|c|c|c|}
\hline Aspek Penilaian & $\begin{array}{c}\text { Persentase } \\
\text { Ketercapaian }\end{array}$ & Kategori \\
\hline $\begin{array}{l}\text { Kemampuan } \\
\text { memahami } \\
\text { masalah }\end{array}$ & $85 \%$ & $\begin{array}{l}\text { Sangat } \\
\text { Baik }\end{array}$ \\
\hline $\begin{array}{l}\text { Kemampuan } \\
\text { merencanakan } \\
\text { penyelesaian }\end{array}$ & $87 \%$ & $\begin{array}{l}\text { Sangat } \\
\text { Baik }\end{array}$ \\
\hline $\begin{array}{l}\text { Kemampuan } \\
\text { melaksanakan } \\
\text { rencana }\end{array}$ & $68 \%$ & Baik \\
\hline $\begin{array}{l}\text { Kemampuan } \\
\text { memeriksa proses } \\
\text { dan hasil }\end{array}$ & $85 \%$ & $\begin{array}{c}\text { Sangat } \\
\text { Baik }\end{array}$ \\
\hline Kesimpulan & $78 \%$ & Baik \\
\hline
\end{tabular}

Berdasarkan Tabel 7, nilai rata-rata tes kemampuan pemecahan masalah sudah mencapai kategori baik yaitu 78.

Selain itu dilakukan juga analisis menggunakan statistika inferensial, yaitu one sample t-test, yang sebelumnya data diuji normalitasnya menggunakan onesample Kolmogorov-Smirnov test dengan bantuan software SPSS Statistics.

Hasil dari one-sample KolmogorovSmirnov test, diperoleh taraf signifikansi $=0,227>\alpha=0,05$. Artinya, data berasal dari populasi yang berdistribusi normal. Hasil dari one sample t-test diperoleh taraf signifikansi $=0,000<\alpha=0,05$, atau $t_{\text {hitung }}=6,496>t_{\alpha}=1,645$. Artinya nilai rata-rata tes kemampuan pemecahan masalah siswa lebih dari 60, dan memenuhi kategori minimal baik.

b. Persentase yang memenuhi minimal kategori baik lebih dari 70\%

Persentase Siswa Mencapai Kemampuan Pemecahan Masalah yang Baik

$x=$ banyaknya siswa yang memiliki kemampuan pemecahan masalah yang baik $=27$ siswa

$n=$ banyaknya siswa yang mengikuti tes = 32 siswa

$$
\frac{x}{n} \times 100 \%=\frac{27}{32} \times 100 \%=84,38 \%
$$

Terlihat bahwa persentase siswa kelas VII A SMP N 2 Pleret yang mencapai kemampuan pemecahan masalah minimal pada kategori baik lebih dari 70\%.

Selain itu, dilakukan juga analisis menggunakan statistika infenrensial, yaitu uji z. Hasil dari uji z, diperoleh $z_{\text {hit }}=$ $1,775>z_{\alpha}=1,645$. Artinya, lebih dari $70 \%$ siswa mencapai kemampuan pemecahan masalah minimal pada kategori baik.

\section{B. Pembahasan}


RPP dikembangkan menurut prinsip pengembangan RPP yang tertera dalam Permendikbud Nomor 22 Tahun 2016 tentang Standar Proses Pendidikan Dasar dan Menengah. Kemudian, langkah kegiatan pembelajaran dikembangkan dengan merujuk pada LKS yang telah dikembangkan. RPP dilengkapi dengan dugaan respon siswa dan alternatif respon guru yang diperoleh dari toughtexperiment dan juga kemungkinan miskonsepsi yang terjadi pada siswa. Contoh dugaan respon siswa dan alternatif respon guru yang dikembangkan dapat dilihat pada Gambar 1.

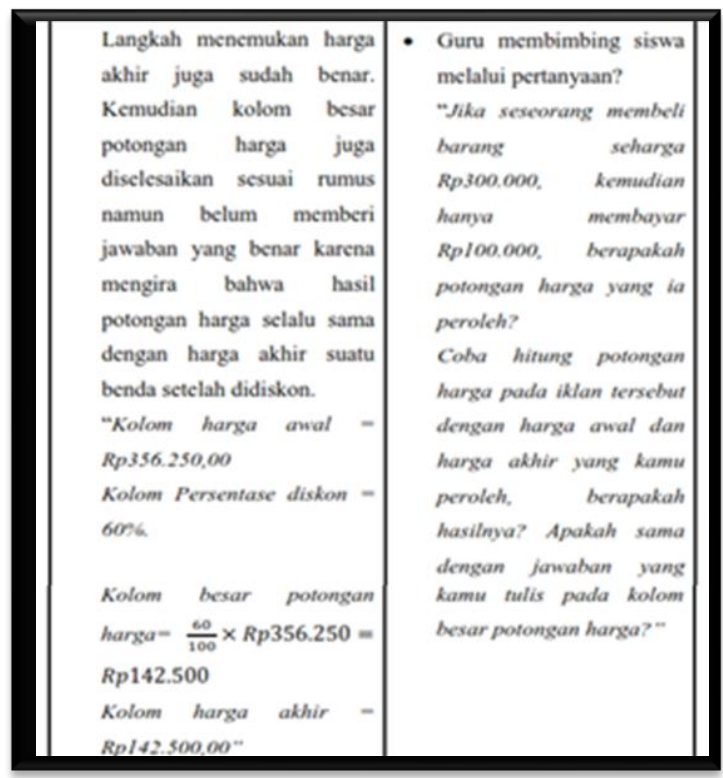

Gambar 1. Contoh Dugaan Respon Siswa dan Alternatif Respon Guru.

Ketika guru telah menuliskan beberapa dugaan, tidak menjamin seluruh siswa akan memiliki respon yang sesuai dengan dugaan tersebut. Terdapat satu permasalahan pada LKS yang berbunyi:

"Suatu ketika Pak Maman membeli 2 karung beras dengan jenis yang berbeda.
Beras "Harum Wangi" bertuliskan "bruto $40 \mathrm{~kg}$, tara 2,5\%" dengan harga $R p$ 390.000,00. Sedangkan, beras "Raja Lele" bertuliskan "neto $40 \mathrm{~kg}$ " dengan harga $R p$ 410.000,00. Pak Maman mencampur kedua beras tersebut dan mengemasnya dengan ukuran neto $1 \mathrm{~kg}$. Berapakah harga jual yang harus diberikan Pak Maman agar mendapat untung 15\%?".

Dalam pembelajaran, peneliti menemukan jawaban siswa yang muncul di luar dugaan. Akibatnya, guru harus sebisa mungkin memikirkan alternatif respon yang tepat untuk mengarahkan siswa pada jawaban yang tepat. Respon siswa yang berbeda dengan dugaan dijadikan oleh peneliti untuk memperbaiki dugaan yang telah dibuat. Contoh jawaban siswa terhadap soal tersebut yang muncul di luar dugaan peneliti dapat dilihat pada Gambar 2.

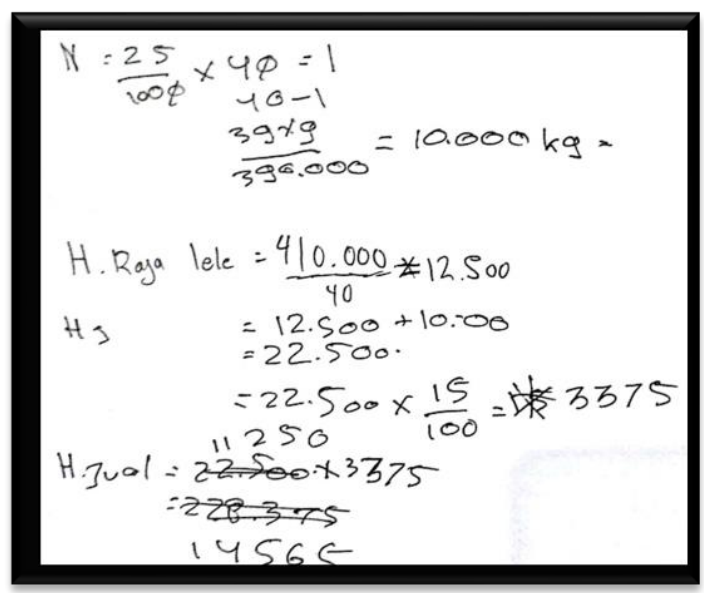

Gambar 2. Contoh Pekerjaan Siswa di Luar Dugaan Guru.

Menurut analisis peneliti, siswa yang jawabannya ada pada Gambar 2 tersebut memiliki kreativitas dan ide yang cukup baik dan unik. Hanya saja, siswa tersebut salah eksekusi terhadap rencana yang 
siswa tersebut miliki. Jadi, siswa tersebut menghitung terlebih dahulu harga beras per kilogram untuk masing-masing jenis beras, padahal jumlah beras keduanya tidak sama. Kesalahan siswa berikutnya adalah cara yang dilakukan siswa dalam mencari keuntungan per kilogram. Siswa mengalikan 15\% dengan jumlah harga 2 jenis beras per kilogram, sehingga diperoleh untung dari $2 \mathrm{~kg}$ beras campuran. Sedangkan siswa tersebut mengasumsikan keuntungan yang ia peroleh melalui perhitungannya adalah keuntungan untuk $1 \mathrm{~kg}$ beras.

Hal ini menunjukkan bahwa HLT memang harus selalu dikembangkan dan direvisi setelah digunakan di dalam pembelajaran. Hal ini sesuai dengan pendapat Simon \& Tzur (2004: 93), yakni karena HLT bersifat dugaan atau hipotesis yang mana belum tentu sesuai dengan proses yang secara aktual terjadi, maka guru perlu memodifikasi setiap aspek dari HLT secara berkelanjutan.

Berdasarkan hasil tes kemampuan pemecahan masalah, persentase ketercapaian setiap aspek kemampuan pemecahan masalah termasuk dalam kategori minimal baik. Namun di antara keempat aspek tersebut, aspek melaksanakan strategi menduduki hasil ketercapaian yang paling rendah yaitu $68 \%$. Menurut hasil analisis peneliti terhadap pekerjaan yang dilakukan siswa, siswa sudah dapat memodelkan namun seringkali tidak teliti ataupun salah eksekusi terhadap rencana atau dalam hal ini model yang telah disusun. Hal tersebut didukung oleh persentase ketercapaian siswa dalam merencanakan strategi yang menempati persentase tertinggi di antara aspek yang lain yaitu $87 \%$.

Berdasarkan hasil penelitian, pengembangan yang dilakukan menghasilkan perangkat pembelajaran dengan pendekatan guided inquiry yang mengacu pada learning trajectory yang berorientasi pada kemampuan pemecahan masalah memenuhi kualitas baik dengan kriteria valid, praktis, dan efektif yang diungkapkan menurut Nieveen (1999: 127), sehingga layak digunakan dalam pembelajaran. Hal ini sejalan dengan pendapat Uno (2016: 14) juga menyampaikan bahwa inquiry bertujuan melatih kemampuan siswa dalam meneliti, menjelaskan, dan memecahkan masalah secara ilmiah. Selain itu, perangkat pembelajaran yang menggunakan learning trajectory dapat membantu siswa dalam memecahkan masalah matematis karena learning trajectory dapat membantu siswa meningkatkan pemahaman konsep. HLT juga bermanfaat sebagai panduan pelaksanaan pembelajaran sekaligus memberikan berbagai alternatif strategi untuk membantu guru mengatasi kesulitan siswa dalam memahami konsep yang dipelajari (Wijaya, 2009).

\section{Penutup}

Penelitian pengembangan ini menghasilkan perangkat pembelajaran berupa RPP dan LKS dengan pendekatan guided inquiry yang mengacu pada learning trajectory yang berorientasi pada 
kemampuan pemecahan masalah dengan model pengembangan ADDIE yaitu Analysis, Design, Development, Implementation, Evaluation.

Perangkat pembelajaran matematika berbasis guided inquiry yang mengacu pada learning trajectory telah terbukti valid, praktis, dan efektif sehinga perangkat ini dapat digunakan dalam proses pembelajaran matematika untuk memfasilitasi tercapainya kemampuan pemecahan masalah yang baik pada siswa SMP kelas VII. Artinya, peneliti lain dapat mengembangkan perangkat pembelajaran serupa untuk materi yang lain ataupun mengembangkan perangkat pembelajaran dengan pendekatan yang lain.

\section{Daftar Pustaka}

Afriansyah, E. A. (2016). Investigasi Kemampuan Problem Solving dan Problem Posing Matematis Mahasiswa via Pendekatan Realistic. Mosharafa: Jurnal Pendidikan Matematika, 5(3), 269-280.

Afriansyah, E. A. (2017). Desain Lintasan Pembelajaran Pecahan melalui Pendekatan Realistic Mathematics Education. Mosharafa: Jurnal Pendidikan Matematika, 6(3), 463474.

Daro, P., Mosher, Corcoran, T.B., et al. (2011). Learning Trajectories in Mathematics: A Foundation for Standards, Curriculum, Assessment, and Instruction. CPRE Research Reports.

Dewi, S. N. dan Minarti, E. D. (2018). Hubungan antara Self-Confidence terhadap Matematika dengan Kemampuan Pemecahan Masalah
Matematik Siswa pada Materi Lingkaran. Mosharafa: Jurnal Pendidikan Matematika, 7(2), 189198. Retrieved from https://journal.institutpendidikan.ac.i $\mathrm{d} /$ index.php/mosharafa/article/view/ mv7n2_4/pdf_1

Kuhlthau, C.C., Maniotes, L.K., \& Caspari, A.K. (2012). Guided Inquiry Design: A Framework for Inquiry in Your School. London: Libraries Unlimited.

Kuhlthau, C.C., Maniotes, L.K., \& Caspari, A.K. (2007). Guided Inquiry: Learning in the 21st Century. London: Libraries Unlimited.

Kemendikbud. (2013). Peraturan Menteri Pendidikan dan Kebudayaan Nomor 65 tahun 2013 tentang Standar Proses.

Kemendikbud. (2014). Peraturan Menteri Pedidikan dan Kebudayaan Nomor 58 Tahun 2014 tentang Kurikulum Sekolah Menengah Pertama

Kemendikbud. (2016). Peraturan Menteri Pedidikan dan Kebudayaan Nomor 22 Tahun 2016 tentang Standar Proses Pendidikan Dasar dan Menengah.

Lestari, K.E. \& Yudhanegara, M.R. (2015). Penelitian Pendidikan Matematika: Panduan Praktis Menyusun Skripsi, Tesis, dan Karya IImiah dengan Pendekatan Kuantitatif, Kualitatif, dan Kombinasi, Disertai dengan Model Pembelajaran dan Kemampuan Matematis. Bandung: PT Reflika Aditama.

National Council of Teacher of Mathematics (NCTM). (2000). Principles and Standars for School Mathematics. Reston, VA: NCTM.

Nieveen, N. (1999). Design Approaches and Tools in Education and Training. Dordrecht: Kluwer Academic Publishers. 
Organisation for Economic Co-operation and Development (OECD). (2016). PISA 2015 Results in Focus. Diakses dari www.oecd.org pada tanggal 5 Mei 2017.

Partnership for $21^{\text {st }}$ century skills (P21). (2015). P21 Framework Definitions. Diakses dari www.p21.org pada tanggal 21 Mei 2017.

Pribadi, B.A. (2009). Model Desain Sistem Pembelajaran. Jakarta: Dian Rakyat.

Sanjaya, W. (2006). Strategi Pembelajaran Berorientasi Proses Pendidikan. Bandung: Kencana.

Shiel, G., Perkins, R., Close, S., et al. (2007). PISA Mathematics: A Teacher's Guide. Dublin: The Stationery Office.

Simon, M.A. (1995). Reconstructing Mathematics Pedagogy from a Constructivist Perspective Journal for Research in Mathematics Education 26(2): 114-145. [online]. Diakses dari http://www.univie.ac.at/constructivis m/archive/fulltexts/3671.html pada tanggal 7 Mei 2017.

Simon, M. A. \& Tzur, R. (2004). Explicating the Role of Mathematical Tasks in Conceptual Learning: An Elaboration of the Hypothetical Learning Trajectory. Mathematical Thinking and Learning, 6(2), 91-104.

Siswoyo, D., Sulistyono, T., Dardiri, A., et al. (2013). IImu Pendidikan. Yogyakarta: UNY Press.

Suherman, E., Turmudi, Suryadi, D., et al. (2001). Strategi Pembelajaran (2001). Strategi Pembelajaran Matematika Kontemporer. Bandung: JICA Universitas Pendidikan Indonesia.

Trianto. (2010). Model Pembelajaran Terpadu: Konsep, Strategi, dan Implementasiya dalam Kurikulum Tingkat Satuan Pendidikan (KTSP). Jakarta: Bumi Aksara.
Uno, H.B. (2016). Model Pembelajaran: Menciptakan Proses Belajar mengajar yang kreatif dan efektif. Jakarta: Bumi Aksara.

Widyoko, E.P. (2009). Evaluasi Program Pembelajaran. Yogyakarta: Pustaka Pelajar.

Widyoko, E.P. (2017). Evaluasi Program Pembelajaran: Panduan Praktis Bagi Pendidik dan Calon Pendidik. Yogyakarta: Pustaka Pelajar.

Wijaya, A. (2009). Hypothetical Learning Trajectory dan Peningkatan Pemahaman Konsep Pengukuran Panjang. Diakses dari http://staff.uny.ac.id/sites/default/file s/penelitian/ariyadiwijayadr/awijayase mnas-mat-2009hlt.pdf. Pada tanggal 17 Mei 2017, Jam 23.03 WIB.

\section{Riwayat Hidup PENULIS}

Viani Kurniawati, S.Pd.

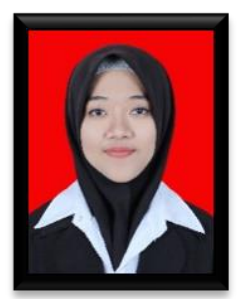

Lahir di Bantul, 27 September 1995. Studi S1 Pendidikan Matematika Universitas Negeri Yogyakarta, lulus tahun 2018.

\section{Ilham Rizkianto, S.Pd., M.Sc.}

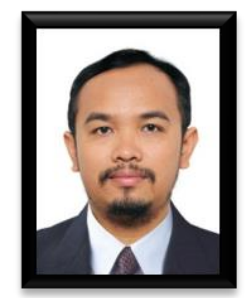

Lahir di Ponorogo, 08 Maret 1987. Dosen S1 di Pendidikan Matematika, Universitas Negeri Yogyakarta. Studi S1 Pendidikan Matematika Singaraja, lulus tahun 2009 dan studi S2 Pendidikan Matematika di UNSRI-UU,

lulus tahun 2012. 